\title{
NILAI KOHESI DAN SUDUT GESER TANAH PADA AKSES GERBANG SELATAN UNIVERSITAS LANCANG KUNING
}

\author{
Virgo Trisep Haris \\ Program Studi Teknik Sipil Universitas Lancang Kuning \\ Jalan Yos Sudarso Km. 8 Rumbai Pekanbaru \\ E-mail : virgo@unilak.ac.id \\ Fadrizal Lubis \\ Program Studi Teknik Sipil Universitas Lancang Kuning \\ Jalan Yos Sudarso Km. 8 Rumbai Pekanbaru \\ E-mail : fadrizal@unilak.ac.id \\ Winayati \\ Program Studi Teknik Sipil Universitas Lancang Kuning \\ Jalan Yos Sudarso Km. 8 Rumbai Pekanbaru \\ E-mail : winayatimt@gmail.com
}

\begin{abstract}
Abstrak
Areal Universitas Lancang Kuning memiliki lahan dengan perbedaan kontur yang cukup curam (berlereng). Beberapa bangunan memerlukan dinding penahan tanah untuk menjaga kesetabilan lereng tanah agar pondasi bangunan tetap dapat stabil menyangga tanah dalam memikul struktur diatasnya. Akses gerbang selatan Universitas Lancang Kuning juga berada pada kondisi tanah yang berlereng, sehingga rawan terhadap bahaya longsor. Untuk mengetahui apakah kondisi lereng tanah akses gerbang selatan Universitas Lancang Kuning aman terhadap bahaya longsor, dilakukan pengujian dengan cara mengebor dan mengambil sampel tanah dilapangan dan dilakukan uji kuat geser di laboratorium. Setelah dilakukan pengeboran tanah pada kedalaman 1 sampai 3,5 meter, serta pengujian cohesi dan sudut geser di laboratorium, dihasilkan pada kedalaman 1,2, 3, dan 3,5 meter, nilai cohesi berturut-turut 0,$18 ; 0,11 ; 0,32$ dan 0,25 $(\mathrm{kg} / \mathrm{cm} 2)$ dan sudut geser 23,5 0; 25,290; 28,170 dan 29,710 maka kategori jenis tanah pasir berlanau dengan tingkat kepadatan sangat lepas. Kekuatan geser tanah relatif dalam kondisi atau keadaan yang sama pada setiap lapisan kedalaman. Dengan kondisi kepadatan sangat lepas, tebing tanah rawan terhadap bahaya longsor, sehingga pembangunan tebing perlu dilakukan sebagai upaya mencegah kelongsoran.
\end{abstract}

Kata Kunci : Kohesi, Lereng, Longsor, Sudut Geser

\begin{abstract}
The area of the University of Lancang Kuning has land with a fairly steep contour difference (slope).Some buildings require a retaining wall to maintain the stability of the ground slope so that the foundation of the building can still be stable to support the soil in carrying the above structure. Access to the southern gateway of the University of Lancang Kuning is also in the condition of the slope soil, so it is prone to landslide
\end{abstract}


hazards.To find out whether the condition of the slopes of the access gate south of the University of Lancang Kuning safe against landslide hazard, tested by drilling and taking soil samples in the field and conducted a shear strength test in the laboratory. After soil drilling at a depth of 1 to 3.5 meters, as well as testing of cohesion and shear angle in the laboratory, produced at depths of 1,2, 3, and 3.5 meters, cohesion values of 0.18;0.11;0,32 and 0,25 ( $\mathrm{kg} / \mathrm{cm} 2)$ and shear angle 23,5 0;25.290; 28,170 and 29,710 , the category of sandy-clad sandy soil with very high density. The shear strength of the soil is relative under the same conditions or circumstances at each depth layer. With very loose density conditions, cliffs of land prone to landslide hazards, so that the cliff construction should be done in an effort to prevent sliding.

Keywords : Cohesion, Slope, Landslide, Shear Angle

\section{A. PENDAHULUAN}

Areal Universitas Lancang Kuning Pekanbaru memiliki lahan yang berkontur dengan tebing yang cukup curam, banyak bangunan-bangunan yang memerlukan dinding penahan tanah untuk menjaga kesetabilan massa tanah agar tetap dapat mendukung dengan baik bangunan diatasnya. Seperti pada bangunan Fakultas Hukum, Fakultas Ilmu Administrasi, Fakultas Ekonomi dan Rusunawa. Universitas Lancang Kuning memiliki lima akses (jalan masuk) dengan dua akses utama, yaitu gerbang timur di jalan Yos Sudarso dan gerbang selatan di jalan Umban Sari. Jalan gerbang timur dalam proses pembangunannya sudah menggunakan dinding penahan tanah untuk menjaga kestabilan struktur jalan tersebut.

Akses gerbang selatan pada sisi yang berbatasan dengan komplek bangunan Politeknik Caltex, kondisinya bertebing dan belum dilakukan perkuatan dengan dinding penahan tanah. Kondisi ini rawan dengan keruntuhan (longsor) yang dapat menyebabkan amblasnya jalan yang ada, keruntuhan lereng juga dapat menimbun areal lahan Politeknik Caltek yang berbatasan dengan jalan tersebut.

$\begin{array}{lrr}\text { Dinding } & \begin{array}{c}\text { penahan } \\ \text { komponen }\end{array} \text { struktur } \\ \text { merupakan } & \text { tanah } \\ \text { bangunan penting untuk jalan raya, dan }\end{array}$

bangunan lingkungan lainnya yang berhubungan dengan tanah yang berkontur atau tanah yang memiliki elevasi yang berbeda cukup tinggi (curam), yang berfungsi untuk menahan massa tanah diatas struktur atau bangunan yang dibuat.

Untuk dapat menghitung dimensi dan kesetabilan dinding penahan tanah, diperlukan penyelidikan tanah untuk mendapatkan engineering properties tanah berupa nilai kohesi dan sudut geser dalam tanah. Nilai kohesi dan sudut geser tanah juga dapat dipergunakan untuk menganalisis apakah tebing atau lereng dalam kondisi aman atau tidak, sebelum dilakukan analisis tentang dimensi dan stabilitas dinding penahan tanah.

\section{B. TINJAUAN PUSTAKA}

Langkah pertama melakukan pemasangan titik bantu dalam bentuk pemasangan dan pengecoran pipa paralon yang lebih dikenal dengan titik kelongsoran tanah. Masalah kelongsoran tanah sering terjadi disebabkan keadaan geografi yang dibeberapa tempat memiliki curah hujan cukup tinggi dan daerah potensi gempa. Curah hujan yang tinggi dianggap sebagai faktor utama kelongsoran karena air dapat mengikis suatu lapisan pasir, melumasi batuan ataupun meningkatkan kadar air suatu lempung 
sehingga mengurangi kekuatan geser (Kusuma, 2016). Kemungkinan longsor akibat hujan masih harus dikaitkan dengan beberapa faktor antara lain topografi daerah setempat, struktur geologi, sifat kerembesan tanah dan morfologi perkembangannya. Permasalahan yang umumnya melatarbelakangi bencana tanah longsor adalah :

a. Kemiringan lereng yang hampir tegak lurus akan berpengaruh terhadap stabilitas lereng. Adanya infrastruktur yang berdiri di atas lereng tidak mungkin dipindah sehingga lahan untuk membuat kemiringan lereng sangat terbatas.

b. Keadaan geografi yang memiliki curah hujan cukup tinggi yang meningkatkan kadar air pori sehingga mengurangi kekuatan geser.

c. Bertambahnya kadar air pori jika terjadi hujan lebat karena kurang berfungsinya saluran drainase pada konstruksi tersebut yang mengakibatkan terhambatnya aliran air yang akan keluar sehingga tekanan air pori meningkat dan berpotensi mengakibatkan kelongsoran.

d. Di atas lokasi longsor telah berubah fungsi dari daerah hijau menjadi pemukiman yang menyebabkan berkurangnya daerah resapan air sehingga terjadi perubahan kandungan air tanah dalam rongga dan akan menurunkan stabilitas tanah.

\section{Kestabilan Lereng}

Pada prinsipnya, cara yang dipakai untuk menjadikan lereng supaya lebih aman (lebih mantap) dapat dibagi dalam dua golongan, yaitu :

a. Memperkecil gaya penggerak atau momen penggerak. Gaya atau momen penggerak dapat diperkecil hanya dengan cara merobah bentuk lereng yang bersangkutan. Untuk itu ada dua cara :

1). Membuat lereng lebih datar, yaitu mengurangi sudut kemiringan

2). Memperkecil ketinggian lereng

b. Memperbesar gaya melawan atau momen melawan. Gaya melawan atau momen melawan dapat ditambah dengan beberapa cara, yang paling sering dipakai ialah sebagai berikut :

1). Dengan memakai "counter weight", yaitu tanah timbunan pada kaki lereng

2). Dengan mengurangi tegangan air pori di dalam lereng

3). Dengan cara mekanis, yang dengan memasang tiang atau dengan membuat dinding penahan

4). Dengan cara injeksi

Saputra S.A

(2017), menganalisis stabilitas lereng tanpa perkuatan dan dengan perkuatan lereng. Penelitian dilakukan di ruas jalan di wilayah perbukitan TNBBS Lampung yang memiliki kondisi geografis terdiri dari tebing dan jurang yang cukup curam, sehingga rawan mengalami kelongsoran. Pada lereng tanpa perkuatan dengan nilai kohesi sebesar 3 $\mathrm{kPa}$ dan sudut geser tanah sebesar $38^{\circ}$, didapat angka keamanan sebesar 0,433 dan 0,4. Hasil tersebut membuktikan struktur lereng tidak aman, maka diperlukan solusi untuk penanganan kelongsoran. Hasil analisis stabilitas kelongsoran lereng yang diperkuat dengan kantilever didapat angka kemanan sebesar 1,852 .

\section{Dinding Penahan Tanah}

Bangunan dinding penahan tanah berguna untuk menahan tekanan tanah lateral yang ditimbulkan oleh tanah urug 
atau tanah asli yang labil. Dinding penahan tanah banyak digunakan pada proyek-proyek : Jalan raya, Irigasi, Pelabuhan, Bangunan ruang bawah tanah (basement), Pangkal jembatan (abutment), dll. Kestabilan dinding penahan tanah diperoleh terutama dari berat sendiri struktur dan berat tanah yang berada di atas pelat fondasi.

Besar dan distribusi tekanan tanah pada dinding penahan tanah, sangat tergantung pada gerakan tanah lateral terhadap DPT.

a. Tipe - tipe dinding penahan tanah

1). Dinding gravitasi, biasanya terbuat dari beton tak bertulang atau pasangan batu, sedikit tulangan diberikan pada permukaan dinding untuk mencegah retakan permukaan.

2). Dinding semi gravitasi, Dinding grafitasi yang bentuknya agak ramping, karena rampingnya pada struktur ini dibutuhkan penulangan beton, namun hanya pada bagian dinding saja.

3). Dinding kantilever, terdiri dari kombinasi dinding dan fondasi beton bertulang yang berbentuk T. Ketebalan DPT ini relatif tipis dan diberi tulangan secara penuh unutk menahan momen dan gaya lintang yang bekerja.

4). Dinding counterfort

5). Dinding beton bertulang yang tipis pada bagian dalam dinding pada jarak tertentu didukung oleh plat atau dinding vertikal yang disebut counterfort. Ruang di atas plat fondasi, diantara counterfort diisi dengan tanah.

6). Dinding krib, dibuat dari balokbalok beton yang disusun menjadi DPT.

7). Dinding Penahan Tanah dengan perkuatan (reinforced earth wall) dinding yang berupa timbunan tanah yang diperkuat bengan material lain. (geosintetik atau metal, dll)

b. Tekanan tanah yang bekerja pada dinding penahan tanah. Tekanan tanah merupakan luas dari diagram tegangan gaya yang terjadi akibat pembebanan, perbedaan tinggi air maupun akibat sifat-sifat tanah (property of soils). Diagram tegangan gaya tersebut dapat dilihat pada gambar 1 .
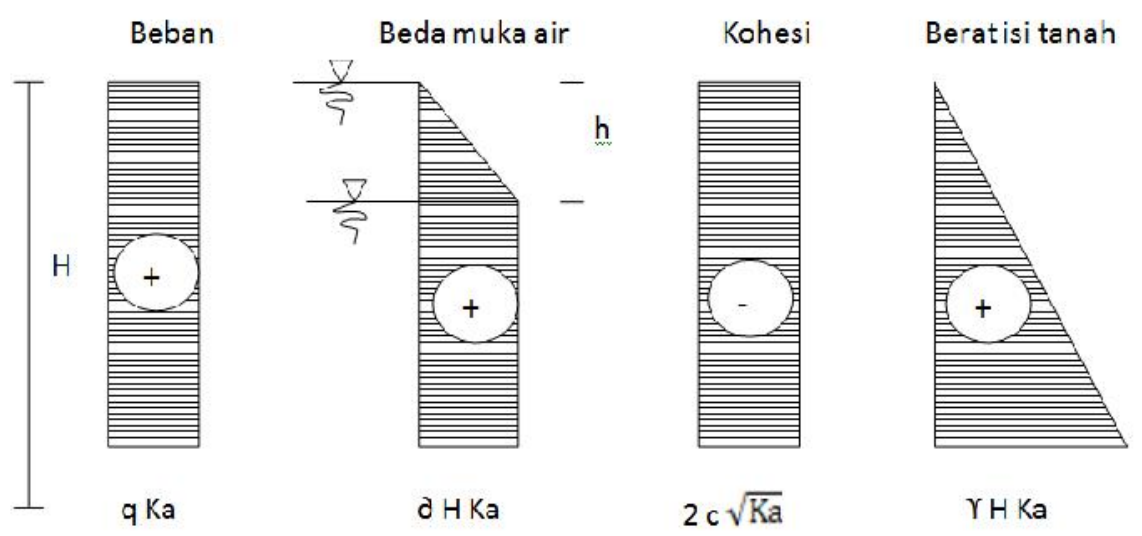

Gambar 1. Tekanan Tanah yang Bekerja pada Dinding Penahan Tanah 


\section{Kohesi dan Sudut Geser}

Kohesi adalah gaya tarik menarik antara partikel dalam tanah, dinyatakan dalam satuan berat per satuan luas. Kohesi tanah akan semakin besar jika kekuatan gesernya makin besar. Nilai kohesi (c) diperoleh dari pengujian laboratorium yaitu pengujian kuat geser langsung (direct shear strength test) dan pengujian triaxial (triaxial test). Salah satu aspek yang memengaruhi nilai kohesi adalah kerapatan dan jarak antar molekul dalam suatu benda. Kohesi berbanding lurus dengan kerapatan suatu benda, sehingga bila kerapatan semakin besar maka kohesi yg akan didapatkan semakin besar. Dalam hal ini, benda berbentuk padat memiliki kohesi yang paling besar dan sebaliknya pada cairan.

Sudut geser dalam merupakan sudut yang dibentuk dari hubungan antara tegangan normal dan tegangan geser di dalam material tanah atau batuan. Sudut geser dalam adalah sudut rekahan yang dibentuk jika suatu material dikenai tegangan atau gaya terhadapnya yang melebihi tegangan gesernya. Semakin besar sudut geser dalam suatu material maka material tersebut akan lebih tahan menerima tegangan luar yang dikenakan terhadapnya. Besaran nilai sudut geser dalam $(\varnothing)$ juga berkaitan dengan tingkat kepadatan suatu jenis tanah, yang dapat dilihat pada tabel 1.

Bahtiar

M.A.

(2016), menggunakan metode statistik untuk mencari persamaan regresi linier kohesi, sudut geser dan nilai konus, yang meliputi uji R2, uji variansi (uji F), uji signikansi (uji t), dan uji validitas. Penelitian ini dilatarbelakangi oleh karena beragamnya keadaan tanah pada setiap daerah, yang tentu saja hal tersebut dapat mengakibatkan daya dukung dan paremeter tanah selalu berubah, yang mencakup sudut geser dan kohesi tanah.

Hafez M (2015), membahas tentang analisa pengaruh kohesi dan sudut geser terhadap perubahan angka keamanan lereng. Perhitungan dilakukan dengan dua cara, yaitu perhitungan secara manual dan perhitungan secara numeric dengan program GeoStudio 2007 - Slope/W. Dalam penelitiannya, Hafez M menggunakan nilai kohesi antara 0 $\mathrm{kN} / \mathrm{m}^{2}$ sampai $200 \mathrm{kN} / \mathrm{m} 2$, dan nilai sudut geser dari $0^{\circ}$ sampai $55^{\circ}$. Hasil penelitian menunjukkan bahwa nilai faktor keamanan lereng akan meningkat seiring dengan bertambahnya nilai kohesi dan sudut geser tanah.

Tabel 1. Besaran Sudut Geser dalam Tanah

\begin{tabular}{lc}
\hline \multicolumn{1}{c}{ Tingkat Kepadatan } & Sudut Geser Dalam $(\boldsymbol{\emptyset})$ \\
\hline Sangat lepas & $<30$ \\
Lepas & $30-35$ \\
Agak padat & $35-40$ \\
Padat & $40-45$ \\
Sangat padat & $>45$ \\
\hline
\end{tabular}

(Sumber : Bowles JE, 1989) 


\section{METODE PENELITIAN}

\section{Lokasi Penelitian}

Pengambilan sampel tanah dilakukan di akses (jalan masuk) gerbang selatan Universitas Lancang Kuning. Sampel tanah kemudian diuji untuk mendapatkan nilai kohesi dan sudut gesernya di laboratorium Program Studi Teknik Sipil Fakultas Teknik Universitas Lancang Kuning.

\section{Bahan dan Alat Penelitian}

Bahan penelitian adalah tanah di akses jalan masuk gerbang selatan Universitas Lancang Kuning. Peralatan yang digunakan : bor tangan, tabung sampel, ekstruder, cincin cetakan sampel, timbangan ketelitian 0,1 gram stop watch, alat uji kuat geser

\section{Prosedur Penelitian}

Prosedur penelitian adalah :

a. Lakukan pengeboran tanah dilapangan sedalam 1 dan 2 meter dengan alat bor tangan pada daerah yang bertebing

b. Pada masing-masing kedalaman pengeboran diambil contoh tanah dengan tabung sampel

c. Sampel tanah dibawa ke laboratorium dan dikeluarkan dengan alat pengeluar sampel (ekstruder)

d. Buat benda uji dengan cara meletakkkan cincin cetakan sampel di mulut tabung sampel dan keluarkan sampel sepanjang lebih kurang $3 \mathrm{~cm}$ sampai cincin cetakan terisi penuh, lalu potong dan ratakan kedua permukaan tanah yang terdapat dalam cincin cetakan

e. Lakukan prosedur diatas untuk 3 buah benda uji

f. Keluarkan benda uji dari cincin cetakan dan timbang benda uji dengan ketelitian 0,1 gram g. Masukkan benda uji ke dalam cincin geser pada alat uji geser yang masih terkunci menjadi satu. Posisi tanah berada diantara dua batu pori

h. Atur posisi stang penekan alat uji kuat geser dalam posisi vertikal dan tepat menyentuh bidang penekan

i. Putar engkol pendorong alat uji geser sampai tepat menyentuh stang penggeser benda uji (dial proving ring tepat akan mulai bergerak)

j. Buka kunci cincin geser, pasang dan atur dial konsolidasi pada posisi nol

k. Berikan beban normal pertama sesuai dengan beban yang diperlukan. Segera setelah pembebanan pertama diberikan, isi bak perendam alat uji geser dengan air sampai penuh sehingga benda uji terendam

1. Putar engkol pendorong sehingga tanah mulai menerima beban geser. Baca dial proving ring dan dial pergeseran setiap 15 detik sampai tercapai beban maksimum atau deformasi $10 \%$ diameter benda uji

m. Berikan beban normal pada benda uji kedua sebesar dua kali beban normal pertama dan ulangi prosedur ke 6 sampai 12 pada benda uji kedua

n. Untuk benda uji ketiga, berikan beban normal sebesar tiga kali beban pertama dan lakukan percobaan dengan cara yang sama dengan benda uji sebelumnya.

\section{HASIL DAN PEMBAHASAN}

Sesuai dengan rencana lokasi penelitian, yaitu pada akses masuk gerbang selatan Universitas Lancang Kuning, dipilih daerah dengan tebing paling curam, yaitu sisi jalan antara markas Waradipa Unilak dengan gedung Poltek Caltex, untuk dilakukan pengeboran guna mendapatkan contoh 
tanah yang nantinya akan dilakukan pengujian dilaboratorium.

Pengeboran tanah dilakukan satu titik pengambilan dengan kedalaman pengambilan sampel masing-masing pada kedalaman $1 \mathrm{~m}, 2 \mathrm{~m}, 3 \mathrm{~m}$ dan $3,5 \mathrm{~m}$. Dari pengujian di laboratorium terhadap sampel-sampel tersebut didapat hasil pengujian sampel seperti pada tabel 2 dan gambar 2.

Nilai kohesi yang didapat dari hasil pengambilan dan pengujian sampel yang diambil dari pengeboran daerah tebing akses gerbang selatan Univ. Lancang Kuning, berkisar antara 0,11 sampai dengan 0,342 atau tidak sama dengan 0 (nol), hal ini menunjukkan bahwa lapisan tanah mengandung jenis tanah yang kohesif (lanau atau lempung). Dengan adanya kandungan tanah kohesif pada lapisan tanah tersebut, lapisan tanah memiliki sifat tarik menarik antar molekulnya, sehingga dapat mendukung kesetabilan lereng dalam batas-batas beban tertentu.

Nilai sudut geser dalam (Ø) yang didapat berkisar antara $23,5^{\circ}$ sampai dengan $29,71^{\circ}$ besarannya ini berdasarkan pada Tabel 1 menunjukkan bahwa tanah sekitar daerah tersebut merupakan tanah dengan jenis pasir berlanau dengan tingkat kepadatan sangat lepas. Kondisi tanah yang sangat lepas menyatakan bahwa lapisan tanah memiliki banyak rongga atau angka pori yang tinggi, sehingga tanah potensial untuk mengalami perubahan volume akibat beban yang diberikan.

Nilai kohesi dan sudut geser dalam $(\varnothing)$ yang didapat ini juga dapat menggambarkan keadaan dilapangan tentang kondisi akses gerbang selatan. Beberapa tempat pada akses tersebut telah mengalami penurunan permukaan (perubahan volume) akibat beban lalu lintas diatasnya, terutama sisi timur didaerah sekitar Posko Waradipa. Bila lapisan tanah hanya terdiri dari pasir lepas, tanpa ada kandungan lanau atau lempung sebagai tanah yang kohesif, perubahan volume atau penurunan permukaan tanah akan lebih besar dari yang ada sekarang.

Dengan telah diketahuinya nilai kohesi dan sudut geser dalam (Ø) lapisan tanah pada akses selatan tersebut, maka upaya-upaya untuk mengetahui karakteristik tanah lebih lanjut serta upaya untuk mencegah terjadinya kelongsoran dapat dilakukan.

Tabel 2. Nilai Kohesi dan Sudut Geser

\begin{tabular}{ccc}
\hline $\begin{array}{c}\text { Kedalaman Sampel } \\
(\mathbf{m})\end{array}$ & $\begin{array}{c}\text { Kohesi } \\
\left(\mathbf{k g} / \mathbf{c m}^{\mathbf{2}}\right)\end{array}$ & $\begin{array}{c}\text { Sudut Geser } \\
\left(\boldsymbol{\emptyset}^{\mathbf{0}}\right)\end{array}$ \\
\hline 1 & 0,183 & 23,5 \\
2 & 0,11 & 25,29 \\
3 & 0,342 & 28,17 \\
3,5 & 0,25 & 29,71 \\
\hline
\end{tabular}




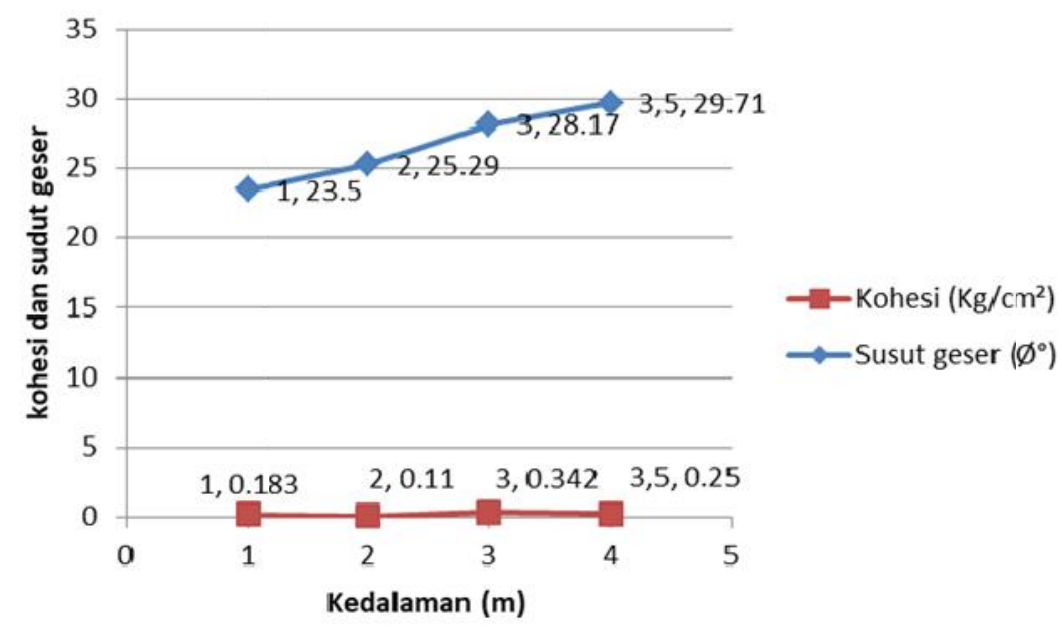

Gambar 2. Hubungan Kedalaman Kohesi dan Sudut Geser

\section{E. KESIMPULAN}

Setelah dilakukan pengeboran pada contoh tanah di kedalaman $1 \mathrm{~m}$, $2 \mathrm{~m}, 3 \mathrm{~m}$ dan $3,5 \mathrm{~m}$, kemudian dilakukan pengujian dilaboratorium didapatkan nilai cohesi dan sudut geser dari tanah tersebut sbb: Kohesi berturut-turut 0,$083 ; 0,11 ; 0,342 ; 0,25\left(\mathrm{~kg} / \mathrm{cm}^{2}\right)$, sudut geser 23,$5 ; 25,29 ; 28,17 ; 29,71\left(\emptyset^{0}\right)$. Hasil analisis, tanah tersebut di atas dikategorikan dengan jenis tanah pasir berlanau dengan tingkat kepadatan sangat lepas. Nilai kohesi dan sudut geser yang didapat dari hasil pengambilan dan pengujian sampel yang besarannya menunjukkan bahwa tanah sekitar daerah tersebut merupakan tanah dengan jenis pasir berlanau dengan tingkat kepadatan sangat lepas. Keadaan kekuatan geser tanah relatif dalam kondisi atau keadaan yang sama pada setiap lapisan kedalaman.

\section{DAFTAR PUSTAKA}

Bahtiar MA., 2016, Korelasi Nilai Kohesi dan Sudut Geser Tanah Dalam dengan Nilai Tahanan Konus Sondir, e-Jurnal Matrik Teknik Sipil.

Bowles JE., 1989, Sifat-sifat Fisis dan

Geoteknis Tanah. Jakarta, Erlangga.

Hafez M., 2015, Analisa Pengaruh

Kohesi dan Sudut Geser Dalam

Terhadap Angka Keamanan

Lereng, Diploma Thesis

Universitas Andalas.

Saputra SA., 2017, Analisis Stabilitas

Lereng Dengan Perkuatan

Dinding Penahan Tanah

Kantilever Dan Geotekstil Pada

Ruas Jalan Lintas Liwa-Simpang

Gunung Kemala KM. 268+550,

Skripsi Jurusan Teknik Sipil

Fakultas Teknik Universitas

Bandar Lampung 